\title{
AKTIVITAS ANTIOKSIDAN DAN SIFAT SENSORIS TEH CELUP CAMPURAN BUNGA KECOMBRANG, DAUN MINT DAN DAUN STEVIA.
}

\section{Total Phenol, Antioxidant Activity And Sensory Characteristic Of Kecombrang Flower, Mint Leaves, And Stevia Leaves Tea Bags.}

Katrien Arumsari, Siti Aminah, Nurrahman

Program Studi S1 Teknologi Pangan

Universitas Muhammadiyah Semarang

Email : katrien.arumsari@gmail.com

\begin{abstract}
Tea is a functional drink that widely used and developed for health purposes. The alternative ingredients for tea making are from plants such as flowers, leaves, skin, fruit, and roots. Teabags,which made from kecombrang flower, mint leaves, and stevia leaves, potentially used as functional drinks,considering the total phenol content and antioxidant activity in each ingredients. The aims of this research is to obtain tea products which contain high total phenol and antioxidant activity with optimum acceptability from kecombrang flower and mint leaves formulations. This study uses a randomized 1:1 ratio design of kecombrang flower: mint leaves, with 5 formulation:(0.4: 1.6), (0.7: 1.3), (1:1), (1.3: 0.7) and (1.6: 0.4), to obtain the datas of Total Phenol Levels, Antioxidant Activities and Sensory characteristic of the tea. The results shows that there is significant effect on total phenol content and antioxidant activity. It results that F1 formulation has the highest amount of total phenol which is $13.907 \mathrm{mg}$ as.galat / $100 \mathrm{~mL}$ as well as the highest antioxidant activity which is $68.84 \% \mathrm{RS}$ A. Sensory testing produces teas with a similar color, while the taste and scent are significantly different.
\end{abstract}

Keywords: tea, kecombrang flower, mint leaf, stevia leaf, total phenol, antioxidant activity, and sensory characteristic.

\section{PENDAHULUAN}

Teh adalah sejenis minuman yang sering diminum dalam keadaan panas, hangat dan dingin. Minuman teh adalah minuman yang paling banyak dikonsumsi masyarakat Indonesia karena rasanya yang segar. Menurut Winarsi (2001) teh dapat dikelompokkan menjadi 2 golongan, yaitu teh herbal dan non herbal. Teh non herbal dikelompokkan lagi menjadi tiga golongan yaitu teh hitam, teh hijau dan teh oolong. Istilah teh juga digunakan untuk minuman yang terbuat dari buah, rempah-rempah atau bagian tanaman lain seperti kulit, bunga, daun dan akar yang diseduh.

$$
\text { Kecombrang merupakan }
$$
tanaman liar yang memiliki banyak manfaat. Kecombrang termasuk dalam golongan Zingiberaceae. Naufalin et al., menjelaskan bahwa penggunaan bunga kecombrang adalah sebagai pemberi citarasa pada masakan. Menurut Nuraini (2014) kecombrang mengandung senyawa alkaloid, saponin, tanin, fenolik, flavonoid, triterpenoid, steroid, 
vitamin, mineral, dan glikosida yang berperan sebagai antimikroba dan antioksidan. Berdasarkan penelitian Rohkyani (2015) aktivitas antioksidan teh celup kecombrang tertinggi yaitu pada bahan teh dari bunga kecombrang dengan pengeringan suhu $65^{\circ} \mathrm{C}$ sebesar $66,43 \%$ sedangkan hasil uji organoleptik teh celup batang dan bunga kecombrang memiliki rasa agak asam dan aroma yang kurang harum. Oleh karena itu, untuk mengurangi rasa asam dan aroma langu teh bunga kecombrang dapat diformulasikan dengan daun mint dan pemberian daun stevia sebagai pemanis alami.

Menurut Riski, (2015) daun mint selain digunakan sebagai penghias hidangan makanan maupun minuman, daun mint juga terkenal sebagai daun yang dapat memberikan efek rasa dingin pada produk makanan.

Daun stevia merupakan salah satu tanaman yang dapat memberi nilai tambah pada minuman fungsional teh. Stevia (Stevia rebaudiana) merupakan pemanis alami rendah kalori yang saat ini banyak digunakan sebagai subtitusi gula.

Berdasarkan uraian dan permasalahan di atas, teh celup campuran bunga kecombrang, daun mint dan daun stevia dapat dijadikan minuman fungsional terkait kandungan dan manfaat dari bahan yang digunakan sehingga peneliti tertarik untuk mengkaji formulasi teh celup campuran bunga kecombrang, daun mint dan daun stevia serta menentukan pengaruh total fenol dan aktivitas antioksidan.

\section{BAHAN DAN METODE}

\section{Bahan dan Alat}

\begin{tabular}{ccc}
\multicolumn{2}{c}{ Bahan utama dalam } \\
pembuatan teh adalah bunga
\end{tabular} kecombrang yang yang dibeli dari Pasar Tradisional Grogolan Kota Pekalongan. Daun mint yang dan daun stevia, kantong teh, benang celup. Sedangkan bahan untuk analisis Follin ciocaltean 10\%, DPPH (1,1-diphenyl-2picryl bydrazi), Natrium bikarbonat $\left(\mathrm{Na}_{2} \mathrm{CO}_{3}\right) 7.5 \%$, metanol, asam galat.

\section{Prosedur Penelitian}

Penelitian dilakukan beberapa langkah yaitu: 1) Pembuatan teh celup campuran bunga kecombrang, daun mint dan daun stevia, 2) Pembuatan seduahan teh, 3) Pengujian teh berupa kadar total fenol, aktivitas antioksidan, sifat sensoris dan itensitas warna.

Pembuatan Teh celup campuran bunga Kecombrang-daun mintdaun stevia

Bahan teh dicuci dengan air bersih, kemudian ditiriskan. Setelah 
itu, bahan dilayukan pada suhu ruang selama 18 jam. Kemudian bahan teh dikeringkan menggunakan oven pada suhu $65^{\circ} \mathrm{C}$ selama $7 \mathrm{jam}$.

Formulasi dilakukan dengan penambahan daun stevia kering sebanyak 1 gram sebagai faktor perlakuan tetap dalam teh celup campuran bunga kecombrang-daun mint-daun stevia. Setelah itu dimasukkan 2 gram campuran teh bunga kecombrang dan daun mint yang telah ditentukan menjadi lima taraf ke dalam kantong celup berukuran 3 gram. Berikut adalah formulasi teh campuran bunga kecombrang-daun mint-daun stevia :

Tabel 1. Formulasi Bahan Baku

\begin{tabular}{lccccc}
\hline \multirow{2}{*}{ Bahan } & \multicolumn{5}{c}{ Berat bahan dalam formulasi (gram) } \\
\cline { 2 - 6 } & F1 & F2 & F3 & F4 & F5 \\
\hline Bunga & 0.4 & 0.7 & 1 & 1.3 & 1.6 \\
Kecombrang & & 1.3 & 1 & 0.7 & 0.4 \\
Daun Mint & 1.6 & 1 & 1 & 1 & 1 \\
Daun Stevia & 1 & 3 & 3 & 3 & 3 \\
Total & 3 & 3
\end{tabular}

Keterangan : Persentase formulasi teh celup bunga kecombrang, daun mint dan daun stevia

$\mathrm{F} 1=13,33 \%: 53,33 \%: 33,34 \%$

$\mathrm{F} 2=23,33 \%: 43,33 \%: 33,34 \%$

$\mathrm{F} 3=33,33 \%: 33,33 \%: 33,34 \%$

$\mathrm{F} 4=43,33 \%: 23,33 \%: 33,34 \%$

$\mathrm{F} 5=53,33 \%: 13,33 \%: 33,34 \%$

\section{Pembuatan Teh Seduh}

Bahan yang akan digunakan untuk dianalisis adalah seduhan dari teh celup. Teh celup masing-masing formula diseduh menggunakan air dengan suhu $90^{\circ} \mathrm{C}$ sebanyak $200 \mathrm{~mL}$ dan gerakkan kantong teh celup naik turun selama 5 menit. Selanjutnya kantong dikeluarkan dari larutan dan didinginkan sampai suhu kamar. Kemudian dianalisa kadar total fenol, aktivitas antioksidan, itensitas warna dan sifat sensori.

\section{Uji Total Fenol (Indrawati, 2015)}

Pengujian sampel dilakukan dengan mengambil 0,2 $\mathrm{ml}$ sampel menggunakan mikropipet dimasukkan ke dalam labu takar $5 \mathrm{ml}$ yang sudah ditutup dengan alumunium foil kemudian ditambah 1,8 $\mathrm{ml}$ folin dan 1,8 $\mathrm{Na}_{2} \mathrm{CO}_{3}$ kemudian divortex selama 30 detik dan inkubasi selaa 35 menit. Dimasukkan kedalam kuvet dan dibaca total fenol pada spektrofotometer dengan panjang gelombang $758.5 \mathrm{~nm}$.

\section{Uji Aktivitas \\ Antioksidan}

(Indrawati, 2015)

Pengujian

antioksidan dilakukan dengan mengambil sampel sebanyak 0,2 $\mathrm{ml}$ larutan uji ditambah 3,8 $\mathrm{ml}$ larutan 1.1-diphenyl-2pycrilhidrazil (DPPH) dalam metanol, divortex kemudian diinkubasi di tempat gelap selama 30 menit. Selanjunya serapan diukur pada panjang gelombang $518 \mathrm{~nm}$. Pembuatan blanko dilakukan dengan 
cara yang sama tetapi mengganti sampel dengan methanol.

Sifat Sensosri (Rahayu, 1998)

Parameter pengujian karakteristik organoleptik teh celup campuran bunga kecombrang-daun mint-daun stevia meliputi : warna, aroma, dan rasa. Uji organoleptik menggunakan skala numerik untuk menilai tingkat penerimaan panelis terhadap produk. Metode yang digunakan yaitu uji hedonik dan uji skoring menggunakan 20 panelis agak terlatih yang diambil dari mahasiswa program studi Teknologi Pangan Universitas Muhammadiyah Semarang. Para panelis diminta mencicipi dan menilai produk teh celup campuran bunga kecombrangdaun mint-daun stevia sesuai dengan lembar penilaian.

\section{Uji Warna Seduhan}

Teh celup campuran bunga kecombrang-daun mint-daun stevia diseduh dengan cara memasukkan satu kantong teh celup kedalam gelas kemudian ditambah $200 \mathrm{ml}$ air panas dan gerakkan kantong naik turun selama 5 menit.

Seduhan di letakan pada beker glass sampai seluruh dasar beker gelas tertutupi oleh seduhan. Chromameter terlebih dahulu dikalibrasi dengan standar warna putih yang terdapat pada alat tersebut. Hasil analisis yang dihasilkan berupa nilai L (Lightning), $a^{*}, b^{*}$. Pengukuran total derajat warna digunakan basis warna putih sebagai standart.

\section{Rancangan Penelitian}

Rancangan penelitian dalam penelitian ini adalah dengan menggunakan rancangan acak lengkap yang terdiri dari satu faktor. Variabel terikat (dependen) adalah sifat sensori, total fenol, aktivitas antioksidan dan itensitas warna. Sedangkan variabel bebas (independen) adalah formulasi penambahan bunga kecombrang dan daun mint. Masing-masing percobaan dilakukan sebanyak 4 kali sehingga diperoleh satuan (unit) percobaan sebanyak 20 unit percobaan.

\section{Analisa Data}

Data hasil analisis kadar total fenol yang diperoleh apabila data normal dan homogen maka dilakukan uji statistik ANOVA (Analysis of Varian) dengan bantuan, jika ada pengaruh di mana $p$-value $<0,05$ maka dilanjutkan uji Ducan. Uji organoleptik yang diperoleh ditabulasi dan dianalisis menggunakan uji non parametrik Friedman. Apabila ada perbedaan perlakuan dimana $p$-value $<0,05$ maka diuji lanjut dengan uji Wilcoxon . 


\section{HASIL DAN PEMBAHASAN}

\section{Kadar Total Fenol}

Penentuan total fenol pada penelitian ini berdasarkan persaman kurva standar asam galat yaitu $\mathrm{y}=$ $0.048788975 \mathrm{x}+0.001860961957$ $(\mathrm{R} 2=0.998)$. Analisis total fenol pada penelitian ini dilakukan untuk bahan baku produk teh. Hasil analisis total fenol pada bahan baku disajikan pada Tabel 2.

Tabel 2. Rerata total fenol bahan baku

\begin{tabular}{lc}
\hline \multicolumn{1}{c}{ Sampel } & $\begin{array}{c}\text { Total Fenol (mg } \\
\text { as. galat/100 }\end{array}$ \\
\hline Bunga & 4.48 \\
Kecombrang & \\
Daun mint & 7.22 \\
Daun stevia & 6.50 \\
\hline \multicolumn{2}{c}{ Hasil perhitungan total fenol }
\end{tabular}

pada Tabel 2. menunjukkan bahwa teh celup bunga kecombrang memiliki kandungan total fenol lebih kecil daripada kandungan total fenol pada teh celup daun mint dan stevia. Senyawa fenol terdiri dari komponen yang sederhana seperti asam fenolat dan komponen polifenol yang lebih kompleks seperti tannin. Flavonoid adalah kelompok yang banyak terkandung dalam tanaman dan biasanya dalam bentuk glikosida.

Hasil analisis kadar total fenol teh celup yang disajikan pada Gambar 1, yang menunjukkan kadar tertinggi adalah teh celup dengan formulasi F1 (0.4:1.6) sebesar $\quad 13.907 \quad \mathrm{mg}$ as.galat/100 mL sedangkan teh celup dengan kadar total fenol terendah adalah teh celup dengan formulsi F5 (1.6:0.4) sebesar $\quad 9.708 \quad \mathrm{mg}$ as.galat $/ 100 \mathrm{~mL}$.

Bila memperhatikan Tabel 6 maka kadar total fenol dipengaruhi oleh komponen fenol pada bahan baku pembuatan teh.

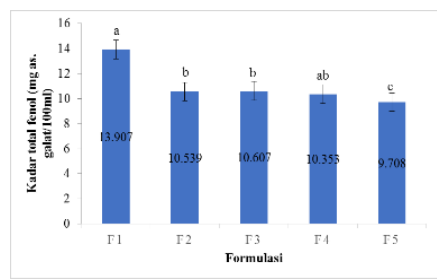

Gambar 1. Rerata kadar total fenol teh celup campuran bunga kecombrang, daun mint dan daun stevia

Hasil analisis statistik menunjukkan variasi jumlah bunga kecombrang dan daun mint pada teh celup sangat berpengaruh terhadap kadar total fenol, hal ini ditunjukkan dengan nilai sig sebesar $0.000(<0.05)$. Uji beda Duncan menunjukkan bahwa antara formulasi F2, F3 dan F4 tidak terdapat perbedaan yang signifikan sedangkan F4 dan F5 juga tidak terjadi perbedaan yang signifikan. Perbedaan yang signifikan terlihat antara formula F1 dan F5.

Kadar total fenol seduhan teh celup memiliki kadar yang cukup tinggi bila dibandingkan dengan standar kadar 
polifenol teh hijau celup pada SNI dalam keadaan kering yaitu minimal 11\%. Pengaruh kadar total fenol pada teh bisa berasal dari kandungan zat aktif yang terkandung pada masing-masing bahan. Hasil uji person tersebut menunjukkan bahwa semakin tinggi proporsi bunga kecombrang pada teh celup, maka kandungan total fenol semakin menurun. Kecenderungan total fenol yang semakin menurun ini diduga karena kandungan total fenol pada bunga kecombrang lebih rendah daripada daun mint. Menurut penelitian Indrawati (2015) menyebutkan pada seduhan teh herbal pacar air dengan metode pengeringan dan konsentrasi pacar air kering 1.5\% memiliki kadar total fenol tertinggi yaitu $10.28 \mathrm{mg}$ as.galat/100 mL.

\section{Aktivitas Antioksidan}

Hasil analisa aktivitas antioksidan teh celup menunjukkan ada pengaruh nyata (sig <0.05) terhadap proporsi bunga kecombrang dan daun mint terhadap aktivitas antioksidan yang dihasilkan. Aktivitas antioksidan masingmasing formulasi dapat dilihap pada Gambar 2.

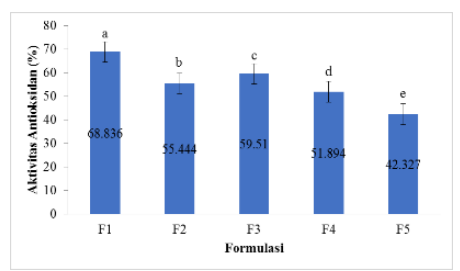

Gambar 2. Rerata Aktivitas Antioksidan Teh Celup Campuran Bunga Kecombrang, Daun Mint dan Daun Stevia Berdasarkan Gambar 2. aktivitas antioksidan pada kelima formula menunjukkan bahwa formula F1 memiliki aktivitas antioksidan paling tinggi yaitu $68.84 \%$, sedangkan F5 memiliki aktivitas antioksidan paling rendah yaitu $42.18 \%$.

Aktivitas antioksidan dalam teh dipengaruhi oleh senyawasenyawa fenol yang terkandung dalam bahan baku pembuatan teh. Senyawa fenol dalam masing masing bahan misalnya bunga kecombrang diantaranya flavonoid, polifenol, antosianin, tanni dan minyak atsiri.

Hasil uji pearson menunjukkan bahwa semakin tinggi proporsi bunga kecombrang pada teh celup, maka aktivitas antioksidannya cenderung menurun. Sedangkan semakin banyak proporsi daun mint maka aktivitas antioksidannya semakin tinggi. Hal ini sesuai dengan penelitian Anggraini (2014) bahwa semakin banyak penambahan ekstrak peppermint pada teh daun pegagan, maka aktivitas antioksidannya semakin meningkat.

Pada penelitian Indrawati (2015) aktivitas antioksidan tertinggi 
pada seduhan teh herbal pacar air dengan metode pengeringan disangrai dan konsentrasi daun pacar air kering $1.5 \%$ yaitu $83.57 \%$. Sedangkan menurut penelitian Rokhyani (2015) aktivitas antioksidan tertinggi adalah pada seduhan teh celup dengan bahan teh bunga kecombrang yang dikeringkan pada suhu pengeringan $65^{\circ} \mathrm{C}$ yaitu sebesar $66.43 \%$.

\section{Hubungan Total Fenol dan \\ Aktivitas Antioksidan Teh}

Untuk mengetahui hubungan kadar total fenol dengan aktivitas antioksidan dilakukan dengan pembuatan kurva pada Gambar 3.

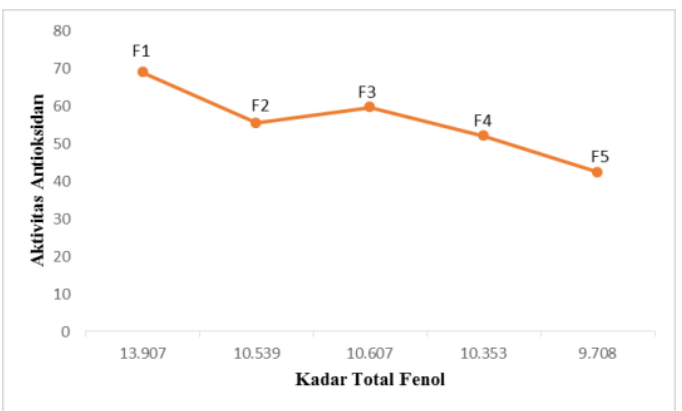

Gambar 3. Kurva hubungan total

fenol dengan aktivitas antioksidan

Uji korelasi Pearson menunjukkan bahwa terdapat hubungan nyata yang positif antara total fenol dan aktivitas antioksidan $(\mathrm{p}<0.05, \mathrm{r}=0.833)$ pada teh celup. Hal ini menunjukkan bahwa semakin tinggi kadar total fenol maka semakin tinggi pula aktivitas antioksidan formula ataupun sebaliknya semakin tinggi aktivitas antioksidannya maka semakin banyak kadar total fenol yang terkandung. Hal ini sesuai dengan penelitian Atmaja (2011), bahwa semakin tinggi kandungan fenolik maka akan memberikan aktivitas antioksidan yang semakin besar.

\section{Analisis Warna (Kecerahan L,} Kemerahan a, Kekuningan b)

Parameter yang diamati yakni L, a dan b. Nilai L menunjukkan kecerahan bahan dan nilainya berkisar antara 0-100. Parameter a menunjukkan nilai warna merahhijau. Warna kisaran merah nilainya 0 sampai +100 sedangkan warna hijau kisarannya 0 hingga -80. Semakin besar nilai positif a berarti warna semakin merah sedangkan jika nilai negatifnya semakin tinggi maka warnanya semakin hijau. Parameter b menunjukkan warna kuning-biru. Warna kuning memiliki kisaran nilai 0 sampai +70 sedangkan warna biru memiliki kisaran nilai 0 sampai -70 (Jaya. 2009). Hasil analisa itensitas warna pada formulasi teh celup campuran bunga kecombrang, daun mint dan daun stevia memberikan pengaruh yang sangat nyata dapat dilihat pada data pada Tabel 3.

Tabel 3. Hasil analisa intensitas warna

Perlakuan Nilai Rata-rata 


\begin{tabular}{ccccc} 
& \multicolumn{1}{c}{ L } & $\mathrm{a}^{*}$ & $\mathrm{~b}^{*}$ & $\mathrm{E}$ \\
\hline F1 & $7.16^{\mathrm{a}}$ & $3.26^{\mathrm{b}}$ & $11.26^{\mathrm{a}}$ & $13.74^{\mathrm{a}}$ \\
F2 & $9.44^{\mathrm{b}}$ & $3.13^{\mathrm{b}}$ & $14.51^{\mathrm{b}}$ & $17.59^{\mathrm{b}}$ \\
F3 & $10.70^{\mathrm{c}}$ & $3.27^{\mathrm{b}}$ & $16.06^{\mathrm{c}}$ & $19.24^{\mathrm{c}}$ \\
F4 & $12.38^{\mathrm{d}}$ & $2.78^{\mathrm{a}}$ & $18.20^{\mathrm{d}}$ & $22.19^{\mathrm{d}}$ \\
F5 & $13.17^{\mathrm{d}}$ & $3.17^{\mathrm{b}}$ & $18.70^{\mathrm{e}}$ & $23.09^{\mathrm{e}}$ \\
\hline
\end{tabular}

Hasil seduhan teh celup semakin banyak proporsi daun mint yang ditambahkan maka semakin rendah nilai kecerahan teh dan nilai itensitas warna teh. Proses pemanasan dalam pembuatan teh celup akan menyebabkan perubahan $\mathrm{pH}$ sehingga terbentuk senyawa feofitin. Ion $\mathrm{Mg}^{+}$yang terdapat di dalam klorofil daun mint dan stevia akan digantikan oleh ion hidrogen $\left(\mathrm{H}^{+}\right.$ yang akan mengakibatkan warna hijau pada daun mint dan stevia berubah warna menjadi kecoklatan sehingga warna filtrat yang dihasilkan cenderung gelap. Klorofil akan berikatan dengan molekul protein pada matriks tanaman sehingga ketika dipapar dengan panas, protein yang melindungi klorofil akan terdenaturasi yang mengakibatkan klorofil dalam bentuk bebas yang sifatnya tidak stabil sehingga ion $\mathrm{Mg}^{2}+$ mudah digantikan ion hidrogen (Bauzzite, 2003).

\section{Analisis Sifat Sensori}

Formulasi teh celup campuran bunga kecombrang, daun mint dan daun stevia meghasilkan lima formula teh celup yaitu F1, F2, F3, F4 dan F5. Karakteristik organoleptik teh diperoleh dengan melakukan uji organoleptik oleh 20 panelis. Parameter yang diuji meliputi warna, aroma dan rasa.

\section{Warna}

Warna merupakan salah satu parameter penting dalam menentukan penerimaan oleh konsumen karena warna merupakan tolak ukur pertama seorang dalam menilai suatu produk. Warna mempunyai arti dan peran penting pada komoditas pangan. Hasil uji organoleptik warna dapat dilihat pada Gambar 4.

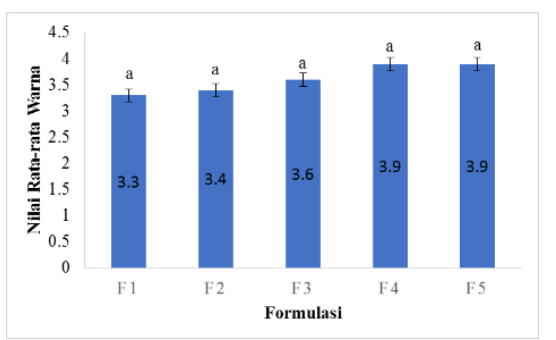

Gambar 4. Rerata tingkat kesukaan panelis terhadap warna teh celup bunga kecombrang, daun mint dan stevia

Hasil analisis statistik kesukaan panelis terhadap warna teh dengan variasi formulasi bunga kecombrang dan daun mint tidak berpengaruh terhadap tingkat penerimaan panelis 
terhadap warna. Hasil uji statistik nonparametrik dengan uji Friedman dengan tingkat kepercayaan 95\% didapatkan nilai p $0.086 \quad(>0.05)$ sehingga dapat disimpulkan bahwa tidak ada pengaruh antar perlakuan.

Menurut penelitian Ellora (2016), bahwa semakin banyak kandungan total fenol yang terekstrak maka warna coklat kemerahan yang dihasilkan semakin pekat. Hal ini diduga karena terjadinya degradasi klorofil pada daun dan kandungan fenol bila bereaksi dengan $\mathrm{O}_{2}$ akan menghasilkan warna coklat.

\section{Aroma}

Aroma suatu produk dapat ditentukan dengan indera hidung melalui bau atau aroma yang ditimbulkan adanya senyawa folatil. Aroma juga merupakan salah satu faktor yang penting untuk menentukan mutu dari suatu produk bahan pangan. Hasil uji organoleptik aroma dapat dilihat pada Gambar 5.

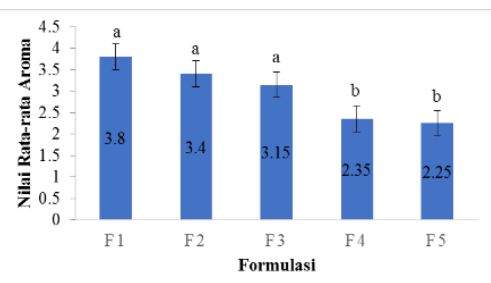

Gambar 5. Rerata tingkat kesukaan panelis terhadap aroma teh celup bunga kecombrang, daun mint dan stevia
Hasil analisis statistik menunjukkan bahwa aroma teh sangat berpengaruh terhadap tingkat kesukaan panelis terhadap aroma teh. Berdasarkan Gambar 5. Aroma pada teh celup dari kelima formulasi yang disukai oleh panelis adalah formulasi F1 (0.4:1.6) semakin banyak proporsi daun mint yang ditambahakan, maka semakin disukai oleh panelis. Kandungan senyawa menthol dan minyak atsiri pada daun mint menimbulkan aroma segar pada teh pada saat diseduh. Selaras dengan penelitian Anggraini (2014), semakin banyak penambahan konsentrasi ekstrak peppermint pada teh daun pegagan maka aroma teh semakin disukai oleh panelis. Aroma yang dihasilkan pada teh celup dengan penambahan daun mint yaitu aroma yang khas serta segar dikarenakan pada daun mint memiliki komponen aroma seperti menthone, isomenthone, menthofuran, carvone, linalool dan piperitone oxide (Verma et al., 2010).

\footnotetext{
Peran aroma suatu produk sangat penting karena akan menentukan daya terima konsumen terhadap produk tersebut. Kandungan peppermint juga mengandung menthol yang merupakan senyawa aromatis
} 
yang berbau tajam dan bersifat volatile atau mudah menguap (Abbas, 2005).

Menurut penelitian Ghassani (2009) menyatakan bahwa aroma dari peppermint efektif dapat meningkatkan performansi memori jangka pendek pada mahasiswa.

Rohdiana (2015) melaporkan secara kimia lebih dari 630 komponen terlibat dalam pebentukan aroma teh. Beberapa diantaranya sudah diketahui pasti konstribusinya seperti linalool dan geraniol.

\section{Rasa}

Rasa dari suatu bahan pangan sangat tergantung pada bahan awalnya. Menurut Winarno (2002) rasa dipengaruhi oleh beberapa faktor, yaitu senyawa kimia, suhu, konsentrasi, dan interaksi dengan komponen rasa yang lain. Hasil uji organoleptik rasa dapat dilihat pada Gambar 6.

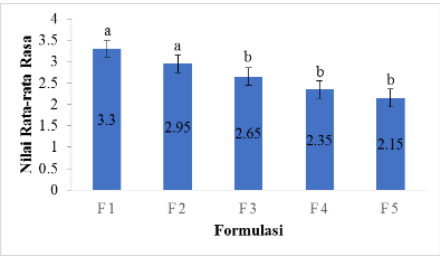

Gambar 6. Rerata tingkat kesukaan panelis terhadap rasa teh celup bunga kecombrang, daun mint dan stevia

Hasil analisis statistik

menunjukkan bahwa aroma teh sangat berpengaruh terhadap tingkat kesukaan panelis terhadap rasa teh. Hasil statistic non parametric dengan uji Friedman didapat nilai $\mathrm{p}$ sebesar 0.007 (<0.01), kemudian dilanjutkan dengan uji Wilcoxon, teh celup bunga kecombrang memiliki rasa yanga agak sepat. Sehingga dengan penambahan daun mint dan stevia membuat teh memiliki rasa lebih manis dan segar. Menurut Putri (2012), rasa dari teh dinilai berdasarkan kekuatan rasa, rasa asing dan rasa pahit. Hasil formulasi dari teh celup campuran bunga kecombrang, daun mint dan daun stevia menghasilkan rasa yang sepat dan khas, rasa asing berupa rasa manis dari stevia serta rasa pahit yang cukup kuat merupakan karakteristik teh tersebut. Rasa sepat pada teh biaasanya karena kandungan senyawa saponin pada bahan baku pembuatan teh. Rasa asing manis yang ditimbulkan pada teh berasal dari senyawa stevioside yang terkandung pada daun stevia yang merupakan pemanis alami. Sedangkan rasama pahit yang timbul disebabkan karena kandungan senyawa tannin pada bahan baku.

\section{Formula Terbaik}

Berdasarkan data hasil variabel dari kadar total fenol, kadar antioksidan, itensitas warna dan sifat 
sensori teh celup bunga kecombrang, daun mint dan daun stevia dengan formulasi terbaik setelah dianalisis secara statistik. Data teh celup disajikan pada Tabel 4.

Tabel 4. Hasil analisis kadar total fenol, aktivitas antioksidan, itensitas warna dan sifat sensori teh celup bunga kecombrang, daun mint dan daun stevia

\begin{tabular}{ccccc}
\hline Formulasi & $\begin{array}{c}\text { Total } \\
\text { Fenol }\end{array}$ & $\begin{array}{c}\text { Aktivitas } \\
\text { Antioksidan }\end{array}$ & $\begin{array}{c}\text { Itensit } \\
\text { as } \\
\text { Warna }\end{array}$ & $\begin{array}{c}\text { Sifat } \\
\text { Sensor } \\
\text { i }\end{array}$ \\
\hline F1 & 13.91 & 68.84 & 13.74 & 3.47 \\
F2 & 10.54 & 55.44 & 17.59 & 3.25 \\
F3 & 10.61 & 59.51 & 19.24 & 3.13 \\
F4 & 10.35 & 51.89 & 22.19 & 2.87 \\
F5 & 9.71 & 42.33 & 23.09 & 2.77 \\
\hline
\end{tabular}

Tabel 4 menunjukkan bahawa teh celup F1 dan F2 tidak berpengaruh secara signifikan terhadap sifat sensori teh, karena panelis masih memberikan nilai ratarata diatas 3 dari nilai $1-5$. Teh pada formulasi F1 merupakan teh dengan kandungan dan daya terima terbaik,

\section{DAFTAR PUSTAKA}

Adawyah.,R. 2008. Pengolahan dan pengawetan ikan. Bumi Aksara. Jakarta

Ajisaka. (2012). Teh Dahsyat Khasiatnya. Surabaya; Penerbit Stomata.

Anjani, P.P., Andrianty, S., \& Widyaningsih, T.D. (2015). Pengaruh Penambahan Pandan Wangi dan Kayu Manis pada Teh Herbal Kulit Salak bagi Penderita Diabetes. Jurnal karena penelitian ini tentang bunga kecombrang maka formula F2 merupakan formulasi terpilih. Teh celup pada formulasi F2 proporsi penambahan bunga kecombrang lebih banyak, kadar total fenol dan aktivitas antioksidanya tinggi, selain itu sifat sensori dari teh masih diterima oleh panelis.

Pemilihan formula F2 selain dari kandungan dan daya terima panelis juga memperhatikan dari segi ekonomi. Harga bunga kecombrang memiliki nilai lebih murah dibandingkan dengan harga daun mint.. Oleh karena itu untuk meminimalisir biaya produksi maka digunakan bahan baku mint yang lebih sedikit dan bunga kecombrang yang lebih banyak. Sehingga bila akan dijual maka harga jual masih tidak terlalu tinggi dan dapat diterima oleh berbagai kalangan masyarakat.

Pangan dan Agroindustri. 3: 203214

Anton, Irawan. 2011. Modul Laboraturium Pengeringan. Sultan Ageng Tirtayasa Press

Babu, P. 2011. In Vitro Studies on the Bearing Ability of Stevia for Stevioside Biosynthesis. Biosci. 
Biotech. Res. Comm. Vol.4 no.1:19-22

Hambali, E.M.Z. Nasution dan E.Herliana. 2005. Membuat Aneka Herbal Tea. (SNI 43242014), Penebar Swadaya, Jakarta.

Hanani E, Mun'im A, Sekarini R. 2005. Identifikasi senyawa antioksidan dalam spons Callyspongia sp. dari Kepulauan Seribu. Majalah Ilmu Kefarmasian 2(3):127-133.

Hasbah, Lajis, Abas, Ali, Sukali, Kikuzaki dan Nakata. 2005. Antioxidant and antibacterial activity of leaves of Etlingera elatior (Zingiberaceae) in Peninsular Malaysia. Journal of Natural Product, 68 (2) : 285-288

Hidayat dan Hutapea. 1991. Inventaris Tanaman Obat Indonesia Edisi I 440-441. Badan Penelitian dan Pengembangan Departemen Kesehatan Republik Indonesia.

Hidayat, F., Rurini Retnowati, dan Soebiantoro. 2013. Isolasi dan Karakterisasi Komponen Minyak Mint dari Daun Mentha arvensis Linn. Hasil Distilasi Air. Jurnal Murid Kimia, Vol. 2, No. 2: 567-573.

Indrawati Dewi. 2015. Aktivitas Antioksidan Dan Total Fenol Seduhan Teh Herbal Daun Pacar Air (Impatiens Balsamina L.) Dengan Variasi Metode Pengeringan Dan Konsentrasi. Skripsi. Fakultas Keguruan Dan Ilmu Pendidikan. Universitas Muhammadiyah Surakarta, Surakarta.
Khotimah, Khusnul. 2014. Karakteristik Kimia Kopi Kawa Dari Berbagai Umur Helai Daun Kopi Yang Diproses Dengan Metode Berbeda. Jurnal Teknologi Pertanian. Vol. 9 No. 1.

Kumalaningsih Sri. 2006. Antioksidan Penangkal Radikal Bebas. Trubus Agrisarana. Surabaya.

Muawanah, A., I. Diajanegara, A. Sa'duddin, D. Sukandar, dan N. Radiastuti. 2012. Penggunaan Bunga Kecombrang (Etlingera elatior) dalam Proses Formulasi Permen Jelly. Valensi. 2(4) : 526-533. ISSN : 1978 - 8193.

Naufalin, R. 2005. Kajian sifat Antimikroba Ekstrak Bunga Kecombrang (Nicolaia speciosa Horan) terhadap Berbagai Mikroba Patogen dan Perusak Pangan. Disertasi. Sekolah Pasca Sarjana. Institut Pertanian Bogor, Bogor.

Naufalin, Rifda dan Rukmini Herastuti Sri. 2011. Potensi Antioksidan Hasil Ekstraksi Tanaman Kecombrang (Nicolaia speciosa, Horan) Selama Penyimpanan. Purwokerto: Fakultas Pertanian Universitas Jenderal Soedirman.

Nuraini, Dini Nuris. (2014). Aneka Manfaat Bunga untuk Kesehatan. Yogyakarta: Gava Media.

Rahayu, W. P. 1998. Penuntun Praktikum Penilaian Organoleptik. Jurusan Teknologi Pangan dan Gizi. Fakultas Pertanian, Institut Pertanian Bogor, Bogor.

Rohdiana.2015. Teh : Proses, Karakteristik \& Komponen 
Fungsionalnya from: https://www.researchgate.net/ publication/286460235 Teh $\mathrm{Pr}$ oses Karakteristik Komponen Fungsionalnya [accessed Feb 09 2018].

Rohkyani Ida, 2015. Aktivitas Antioksidan Dan Uji Organoleptik Teh Celup Batang Dan Bunga Kecombrang Pada Variasi Suhu Pengeringan. Skripsi. Program Studi Pendidikan Biologi, Fakultas Keguruan dan Ilmu Pendidikan, Universitas Muhammadiyah Surakarta

Sarastani, Dewi; Suwarna T. Soekarto; Tien R. Muchtadi; Dedi Fardiaz dan Anton Apriyanto., (2002), Aktivitas Antioksidan Ekstrak dan Fraksi Ekstrak Biji Atung., Jurnal Teknologi dan Industri Pangan. Vol. XIII. No. 2. 149156.

Susiwi, S. 2009. Penilaian Organoleptik. Universitas Pendidikan Indonesia. Bandung

Testiningsih Riski F. 2015. Aktivitas Antioksidan Teh Daun Alpukat Dengan Variasi Penambahan Daun Mint Dan Daun Stevia. Skripsi. Program Studi Pendidikan Biologi, Fakultas Keguruan dan Ilmu Pendidikan, Universitas Muhammadiyah Surakarta

Tjitrosoepomo, Gembong. 2010. Taksonomi Tumbuhan Obat- obatan. Yogyakarta : Gajah Mada University Press.

Valianty, K. 2002. Potensi Antibakteri Minyak Bunga Kecombrang. Skripsi. Jurusan Teknologi Pertanian. Fakultas Pertanian. Universitas Jenderal Soedirman Purwokerto.

Verma, A. Alpana, s. 2014. Optimization and Quality assessment of LowCalorieHerbal Tea Sweetened with Stevia (Stevia rebaudiana).Journal of Medical Research and Development. 3(2):134-137.

Wijekoon, Jeevani Osadee, M. M., Karim, A. A. and Bhat, R. (2011). Evaluation of Nutritional Quality of Torch Ginger (Etlingera elatior Jack.) Inflorescence. International Food Research Journal, 18, 1415-1420.

Winarno FG. 2002. Kimia Pangan dan Giz̧i. Jakarta : PT. Gramedia

Winarsi,H.2001. Antioksidan Alami dan Radikal Bebas. Penerbit Kanisius. Yogyakarta

Yamin, M., Dewi, FA., dan Faizah, H. 2017. Lama Pengeringan Terhadap Aktivitas Antioksidan Dan Mutu Teh Herbal Daun Ketepeng Cina (Cassia Alata L.). Jom FAPERTA Vol. 4 No.2. Jurusan Teknologi Pertanian. Fakultas Pertanian. Universitas Riau. 